\title{
Features of development of hametophytes Botrychium multifidum (S.G. Gmel.) Rupr. culture in vitro
}

\author{
Igor Krinitsyn ${ }^{1}$, Dmitry Zontikov ${ }^{1 *}$, Svetlana Zontikova ${ }^{1}$, A. Baghizadeh ${ }^{2}$, P. Behroozi $^{2}$ and \\ Roman Sergeev ${ }^{3}$ \\ ${ }^{1}$ Kostroma State University, 156000, 14, 1st of May St., Kostroma, Russia \\ ${ }^{2}$ 7631818356, Kerman, Graduate University of Advanced Technology, Iran \\ ${ }^{3}$ Volga State University of Technology, 424000, 3. Lenin Sq., Yoshkar-Ola, the Republic of Mari El, \\ Russia
}

\begin{abstract}
The work is devoted to studying the influence of the type of culture medium and $\mathrm{pH}$ on the development of gametophytes Botrychium multifidum in vitro. The spores obtained from sterilized sporangia were suspended in liquid nutrient media with initial inoculum of 10000 spores per $1 \mathrm{ml}$. Nutrient media tested in the study were composed of full Murashige and Skoog or Knudson mineral salts supplemented with kinetin $(1 \mathrm{mg} / \mathrm{l})$ and $\mathrm{pH}$ level 4.8-6.4. All stages of development, from spore germination to thallus and gametophyte formation, were observed in tissue culture. A low level of germinating spores was noted.
\end{abstract}

\section{Introduction}

Ferns are one of oldest groups of vascular plants, however, there is lack of information on the generative phase of fern development [1]. There are also some disputable issues in fern systematization and phylogeny that cannot be solved solely on the basis of sporophyte morphology or molecular phylogenetic data without comparison of generative phases of various species [2-5]. The family Ophioglossaceae Martynov has a simpler morphological and anatomical structure of vascular plants. It attracts major scientific interest due to unique plant morphology and organ structure that are very different from that of the evolutionary younger fern species [6-8]. Botrychium multifidum (S.G. Gmel.) Rupr. is one of the most widespread species of this family. Small populations of this species often composed of a few dozens of individuals were found in the northern hemisphere and less frequently in the southern part of the globe [4,9]. To date, there is no single, universally accepted systematic species name for B. multifidum [9] or Osmunda multifida [10] or Sceptridium multifidum (Ophioglossaceae) [6-8, 11]. In our study, we will adhere to the well-known (although obsolete in terms of systematics) name of the species $B$. multifidum. The structure of the spores in Botrychium species is well-studied [12], however, there is no published information on number of sporangia and spores produced by these ferns. According to

${ }^{*}$ Corresponding author: zontikovdn@mail.ru 
literature, members of Ophioglossaceae family produce from 1500 to 15000 spores [1]. Gifford and Brandon investigated the development of B. multifidum gametophyte, but their study is based only on the mature gametophyte morphology owing to the difficulty of spore germination [13].

Cultivation of spores under sterile in vitro conditions can be used for detailed investigation of the early stages of gametophyte development. This method also allows avoiding some common mistakes resulting from ex vitro observations. To our knowledge, the only attempt to use tissue culture for gametophyte ontogenesis research was performed by Whittier who reported cultivation $B$. dissectum protallium on the nutrient medium [14]. Sucrose added to the medium supported development of gametophytes without mycorrhizal fungi.

The goal of the present study was to investigate in detail the main stages of $B$. multifidum gametophyte development following spore germination in vitro.

\section{Materials and methods}

Twelve plants of B. multifidum were collected in Kologrivski area of the Kostroma region, Russia, and planted in an experimental plot of the Kostroma State University.

Sporangia were harvested from the plants in late July - beginning of August, approximately two weeks before opening, to simplify sterilization process. Before culture initiation, the number of sporangia and spores in them were counted using Goryaev counting chamber.

Sporangia were washed 10 minutes in $0.05 \%$ potassium permanganate solution and sterile water. Specimens were sterilized in a laminar airflow cabinet with 1 minute $70 \%$ of ethyl alcohol followed by 15 minutes in 3\% sodium hypochlorite solution, then washed in sterile water 3 times.

After sterilization, sporangia were put in sterile $2 \%$ sucrose solution and spores were separated mechanically using Potter-Elvehjem's homogenizer (Sigma-Aldrich, Boston, USA). The concentration of spores in the solution was 10000 spores $/ \mathrm{ml}$. Then the suspension of spores was dispensed with a pipette to the nutrient medium in Petri dishes, 1 $\mathrm{ml}$ with 10000 spores per dish. Petri dishes with spores were kept on light with illumination of 30000 Lux and a photoperiod of $18 / 6,25^{\circ}$. Two types of media were tested for spore germination: Murashige and Skoog (MS) medium [15,16] with $100 \mathrm{mg} / \mathrm{l}$ meso-isonitol, 2 $\mathrm{mg} / \mathrm{l}$ glycine, $0.5 \mathrm{mg} / \mathrm{l}$ thiamine, $0.5 \mathrm{mg} / \mathrm{l}$ pyridoxine and Knudson medium [13] with 100 $\mathrm{mg} / \mathrm{l}$ meso-isonitol, and $0.4 \mathrm{mg} / \mathrm{l}$ thiamine. In the second experiment, MS media was supplemented with different growth regulators: $1.0 \mathrm{mg} / 1 \mathrm{Kn}, 0.1 \mathrm{mg} / 1 \mathrm{NAA}, 0.1 \mathrm{mg} / 1 \mathrm{IAA}$, or $0.1 \mathrm{mg} / \mathrm{l} \mathrm{IBA}, 2-20 \mathrm{~g} / 1$ sucrose, and $5 \mathrm{~g} / \mathrm{l}$ agar. Media $\mathrm{pH}$ varied from 4.8 to 6.4 . Three Petri dishes were used for each experiment. An experiment on the effect of $\mathrm{pH}$ was performed after obtaining preliminary results from a previous experiment. Spores were cultivated in Petri dishes, the protallia were cultivated in rotary $25 \mathrm{ml}$ tubes.

The photographs of gametophyte development were taken with microscope Biomed-3 equipped with «Samsung» digital camera. Measurements of spores, protonema and thallus were done using micrometer. The statistical analysis was performed using Microsoft Excel and Matrix.

\section{Results}

One of the main parameters for determining the influence of the composition of the nutrient medium on spore germination is the numerical ratio of the number of spores placed on the nutrient medium and the cells that started mitotic division. Number of sporangia and spores 
in the collected plants and some of their morphological characteristics are presented in Table 1.

Table 1. Some morphological characteristics of the generative parts of four B. multifidum plants at the time of the collection. Table presents mean values with standard errors.

\begin{tabular}{|c|c|c|c|c|c|}
\hline $\begin{array}{c}\text { Plant } \\
\text { no. }\end{array}$ & $\begin{array}{c}\text { Plant ontogenetic } \\
\text { stage }\end{array}$ & $\begin{array}{c}\text { Sporangium } \\
\text { height, cm }\end{array}$ & $\begin{array}{c}\text { Number } \\
\text { of } \\
\text { sporangia } \\
\text { per plant }\end{array}$ & $\begin{array}{c}\text { Number of spores in } \\
\text { one sporangium, 10 } \\
\text { psc./plant }\end{array}$ & $\begin{array}{c}\text { Diameter of } \\
\text { spores, mm }\end{array}$ \\
\hline 1 & $\begin{array}{c}\text { Young plant with } \\
\text { spores (sp1) }\end{array}$ & 14 & 805 & $3345 \pm 126$ & $0.034 \pm 0.003$ \\
\hline 2 & $\begin{array}{c}\text { Young plant with } \\
\text { spores (sp1) }\end{array}$ & 12 & 635 & $3129 \pm 242$ & $0.041 \pm 0.002$ \\
\hline 3 & $\begin{array}{c}\text { Middle-aged plant } \\
\text { with spores (sp2) }\end{array}$ & 20 & 1267 & $4012 \pm 126$ & $0.035 \pm 0.002$ \\
\hline 4 & $\begin{array}{c}\text { Middle-aged plant } \\
\text { with spores (sp2) }\end{array}$ & 14 & 943 & $3589 \pm 126$ & $0.039 \pm 0.003$ \\
\hline
\end{tabular}

The number of sporangia and the spores contained in them depends on a very large number of factors, such as the stage of plant development, growth conditions, its ploidy, etc. In our study, we did not set the task of determining the number of spores in sporangia depending on these factors, it was important for us to determine the approximate percentage of spore germination, and for this it was necessary to determine their average number in one sporangia.

As a result of the experiments, on the nutrient medium MS, in the best case, 9 mature gametophytes were formed per 10000 spores (Table 2). It is worth noticing that we can only compare gametophyte development in different media in vitro since there are no records on the number of gametophytes normally developed by this species under natural conditions.

Table 2. Number of germinated spores and developed protonemas, prothallia and mature gametophytes of B. multifidum on MS and Knudson media (three replicates of three Petri dishes).

Table presents mean values with standard errors, triplicate experiments

\begin{tabular}{|c|c|c|c|c|}
\hline $\begin{array}{c}\text { Plant } \\
\text { no. }\end{array}$ & $\begin{array}{c}\text { Number of germinated } \\
\text { spores (\%) }\end{array}$ & $\begin{array}{c}\text { Number of } \\
\text { developed } \\
\text { protonemas (\%) }\end{array}$ & $\begin{array}{c}\text { Number of } \\
\text { developed } \\
\text { prothalliums (\%) }\end{array}$ & $\begin{array}{c}\text { Number of developed } \\
\text { mature gametophytes }\end{array}$ \\
\hline \multicolumn{5}{|c|}{ MS medium } \\
\hline 1 & $0.95 \pm 0.08$ & $0.12 \pm 0.01$ & $0.08 \pm 0.01$ & 9 \\
\hline 2 & $0.87 \pm 0.06$ & $0.09 \pm 0.01$ & $0.06 \pm 0.01$ & 7 \\
\hline 3 & $0.76 \pm 0.08$ & $0.08 \pm 0.01$ & $0.07 \pm 0.01$ & 8 \\
\hline 4 & $0.79 \pm 0.07$ & $0.09 \pm 0.01$ & $0.05 \pm 0.01$ & 4 \\
\hline \multicolumn{5}{|c|}{ Knudson medium } \\
\hline 1 & $0.43 \pm 0.10$ & $0.03 \pm 0.01$ & $0.02 \pm 0.01$ & 1 \\
\hline 2 & $0.35 \pm 0.09$ & $0.04 \pm 0.01$ & $0.02 \pm 0.01$ & 2 \\
\hline 3 & $0.29 \pm 0.07$ & $0.02 \pm 0.01$ & $0.02 \pm 0.01$ & 2 \\
\hline 4 & $0.41 \pm 0.07$ & $0.02 \pm 0.01$ & $0.02 \pm 0.01$ & \\
\hline
\end{tabular}


The highest spore germination and highest number of protonemas and prothallia were observed on MS media with $\mathrm{pH}=5.6$ supplemented with NAA (Table 3). Spore germination on this medium started earlier than in other variants and resulted in 10 fully developed mature gametophytes compared to 0-5 gametophytes formed on media with other growth regulators (Table 3 ), and the beginning of spore germination was noted already on the 5 th day.

Table 3. Effect of growth regulators and media $\mathrm{pH}$ on number of germinated spores and number of developed protonemas, prothallia and mature gametophytes of $B$. multifidum cultured on MS medium media (three replicates of three Petri dishes). Table presents mean values with standard errors, triplicate experiments

\begin{tabular}{|c|c|c|c|c|c|}
\hline $\mathrm{pH}$ & $\begin{array}{l}\text { Number of } \\
\text { germinated } \\
\text { spores (\%) }\end{array}$ & $\begin{array}{c}\text { Day } \\
\text { germination } \\
\text { started }\end{array}$ & $\begin{array}{c}\text { Number of } \\
\text { developed } \\
\text { protonemas (\%) }\end{array}$ & $\begin{array}{c}\text { Number of } \\
\text { developed } \\
\text { prothalliums } \\
(\%)\end{array}$ & $\begin{array}{c}\text { Number of } \\
\text { developed } \\
\text { mature } \\
\text { gametophytes }\end{array}$ \\
\hline \multicolumn{6}{|c|}{ NAA $0.1 \mathrm{mg} / 1$} \\
\hline 4.8 & 0 & - & 0 & 0 & 0 \\
\hline 5.2 & $0.08 \pm 0.01$ & 5 & $0.03 \pm 0.01$ & $0.04 \pm 0.01$ & 3 \\
\hline 5.6 & $0.84 \pm 0.02$ & 5 & $0.08 \pm 0.01$ & $0.07 \pm 0.01$ & 10 \\
\hline 6.0 & $0.69 \pm 0.02$ & 6 & $0.05 \pm 0.01$ & $0.05 \pm 0.01$ & 6 \\
\hline 6.4 & $0.11 \pm 0.01$ & 6 & $0.02 \pm 0.01$ & $0.02 \pm 0.01$ & 1 \\
\hline \multicolumn{6}{|c|}{ IBA $0.1 \mathrm{mg} / 1$} \\
\hline 4.8 & - & - & - & - & - \\
\hline 5.2 & $0.15 \pm 0.02$ & 7 & $0.04 \pm 0.01$ & $0.03 \pm 0.01$ & 2 \\
\hline 5.6 & $0.39 \pm 0.03$ & 7 & $0.02 \pm 0.01$ & $0.02 \pm 0.01$ & 4 \\
\hline 6.0 & $0.21 \pm 0.01$ & 8 & $0.02 \pm 0.01$ & $0.02 \pm 0.01$ & 4 \\
\hline 6.4 & $0.09 \pm 0.02$ & 8 & 0 & 0 & 0 \\
\hline \multicolumn{6}{|c|}{ IAA $0.1 \mathrm{mg} / \mathrm{l}$} \\
\hline 4.8 & 0 & - & 0 & 0 & 0 \\
\hline 5.2 & $0.10 \pm 0.01$ & 7 & $0.04 \pm 0.01$ & $0.03 \pm 0.01$ & 1 \\
\hline 5.6 & $0.21 \pm 0.01$ & 8 & $0.05 \pm 0.01$ & $0.04 \pm 0.01$ & 4 \\
\hline 6.0 & $0.18 \pm 0.02$ & 8 & $0.04 \pm 0.01$ & $0.02 \pm 0.01$ & 2 \\
\hline 6.4 & $0.07 \pm 0.01$ & 9 & $0.03 \pm 0.01$ & $0.03 \pm 0.01$ & 0 \\
\hline \multicolumn{6}{|c|}{ Kinetin $1.0 \mathrm{mg} / 1$} \\
\hline 4.8 & 0 & - & 0 & 0 & 0 \\
\hline 5.2 & $0.11 \pm 0.02$ & 10 & $0.05 \pm 0.01$ & $0.03 \pm 0.01$ & 4 \\
\hline 5.6 & $0.60 \pm 0.01$ & 10 & $0.06 \pm 0.02$ & $0.04 \pm 0.01$ & 5 \\
\hline 6.0 & $0.53 \pm 0.01$ & 11 & $0.04 \pm 0.01$ & $0.03 \pm 0.01$ & 0 \\
\hline 6.4 & $0.13 \pm 0.01$ & 12 & $0.03 \pm 0.01$ & 0 & 0 \\
\hline
\end{tabular}

Diameter of spores placed on culture media increased by $0.004 \mathrm{~mm}$ in two days and trilete tetradic cicatrix was observed on a proximal part of the spore. Mitotic division in the spores was recorded after four days of culture. After seven - eight days, spore coat teared apart along a trilete tetradic cicatrix and the primary rhizoid appeared. Simultaneously, the coat protonema developed inside the spores. The process of rhizoid and protonema development continued for 25 days. Protonema appeared as a 0.06-0.08 mm long structure consisting of 8-12 cells, with a single or several branches. Prothallia development continued for 50-70 days and was accompanied by the increase of protonema size to $0.2-0.5$ $\mathrm{mm}$. Mature gametophytes developed during the following 20-40 days. The gametophytes were disk-shape structures $0.9-1.8 \mathrm{~mm}$ in diameter and were formed by parenchymatous tissues. Archegonia were located closer to the center of the thallus. For germination of $B$. multifidum spores in an in vitro culture, we recommend using MS nutrient medium supplemented with $0.1 \mathrm{mg} / 1 \mathrm{NAA}, \mathrm{pH}-5.6$. 


\section{Discussion}

The number of sporangia and spores developed by fern species depend on multiple factors such as the development stage of a plant, environmental conditions, plant ploidy, etc. that were not in the focus of this study. In the majority of homosporic ferns, gametophyte development can be divided into 4 stages: 1 . spore germination; 2 . protonema stage; 3 . prothallium formation; 4. mature thallus [1]. All these stages were identified during $B$. multifidum spore cultivation in vitro. The size of the spores did not increase significantly during the germination likely because they were obtained from unopened sporangia as opposed to the method used by Whittier [14]. Due to a specific structure of a spore coat, spore may remain on the gametophyte until it reaches the stage of prothallium and, sometimes, until the formation of mature thallus, thus some cells may remain inside the coat for a long time. According to the type of germination based on the classification by Nayar and Kaur and taking into account the absence of clear polarity and direction of cell division, cell division in B. multifidum spores can be described as amorphous [17].

The size of $B$. multifidum gametophyte is of a great interest. There is no accurate indication of the gametophyte size in the literature. The size of prothallia of $B$. dissectum and $B$. virginianum varied from $1 \mathrm{~mm}$ to $20 \mathrm{~mm}$ [17]. In our work, mature thallus of $B$. multifidum were up to $2 \mathrm{~mm}$ in size. The disk shape of the gametophyte observed in this study for $B$ multifidum was also reported for other Botrichium species.

In this study, development of B. multifidum gametophyte in vitro continued for 4-5 months. It is likely that in natural conditions, taking into account relatively late period of spore bearing, a significant amount of spores should be germinating the following year.

\section{Conclusion}

In this study, all developmental stages from spore germination to formation of mature gametophytes were observed for B. multifidum cultured in vitro. This and other reports on fern gametophyte development suggest that duration of developmental stages, some morphological characteristics and even sexual gametophyte development in tissue culture can be different from that in natural conditions. However, taking into account advantages of tissue culture method such as significant simplification of observations and elimination of human mistakes during species identification allow us to recommend this method for gametophyte development research in rare ferns.

\section{References}

1. E.M. Arnautova, Gametophytes of equisporous ferns, (Univ. Press, St. Petersburg, 2008)

2. G. W. Rothwell and R. A. Stockey, American Journal of Botany, 76, 637-44 (1989)

3. G.M. Kovacs, T. Balazs, and Z. Penzes, Mycorrhiza, 17, 597-605 (2007)

4. D. R. Farrar, Systematics and taxonomy of genus Botrychium, http://www.public.iastate.edu/herbarium/botrychium/Moonwort-Systematics.pdf, (2011)

5. W.N. Shinohara, Y. Nakato, Yatabe-Kakugawa, T. Oka, J. Kun Kim and N. Murakami, Systematic Botany, 38, 564-570 (2013)

6. E. Schuettpelz, H. Schneider, A. Smith, P. Hovenkamp, J. Prado, G. Rouhan, A. Salino, M. Sundue, T. Almeida, B. Parris, E. Sessa, A. Field, A. de Gasper, C. Rothfels, M. Windham, M. Lehnert, B. Dauphin, A. Ebihara, S. Lehtonen and X. Zhou, Journal of Systematics and Evolution, 54 (2016) 
7. M. Kato, The Garden's Bulletin Singapore, 40, 1-14 (1987)

8. W. Hauk, C. Parks, M. Chase, Molecular phylogenetics and evolution, 28, 131-51 (2003)

9. D.G. Anderson, Botrychium multifidum (Gmel.) Rupr. (leathery grapefern): a technical conservation assessment. (USDA Forest Service, Rocky Mountain Region. 2005)

10. I. Sokolova, Y. Ivanenko, Taxon, 66, 1220-22 (2017)

11. B. Dauphin, J. Grant, D. Farrar, C. Rothfels, Molecular Phylogenetics and Evolution 120 (2017)

12. Tom A. Ranker, A.F. .Tyron and B. Lugardon, Systematic Botany, 18, 377 (1993)

13. E.M. Gifford and D.D. Brandon, Amer. Fern Journ., 68, 71-75 (1978)

14. Dean P. Whittier, Bot. Gaz., 133, 336-39 (1972)

15. T. Murashige and F. Skoog, Physiologia Plantarum, 15, 473-97 (1962)

16. D. Zontikov, S. Zontikova, R. Sergeev, A. Shurgin, In vitro propagation of rubus chamaemorus $L$. and rubus arcticus $L$. in International Multidisciplinary Scientific GeoConference Surveying Geology and Mining Ecology Management, SGEM. 14, 397-403 (2014)

17. B.K. Nayar, S. Kaur, Journ. Palyn, 4, 1-14 (1968)

18. Dean P. Whittier and R. Dale Thomas, International Journal of Plant Sciences, 154, 68-74 (1993) 